Article

\title{
Analysis of Metrological Quality and Mechanical Properties of Models Manufactured with Photo-Curing PolyJet Matrix Technology for Medical Applications
}

\author{
Tomasz Kozior*(D), Jerzy Bochnia (D), Damian Gogolewski (D), Paweł Zmarzły (D), Mateusz Rudnik (D), Wiktor Szot (D), \\ Paweł Szczygieł (D) and Mateusz Musiałek
}

\section{check for}

updates

Citation: Kozior, T.; Bochnia, J.;

Gogolewski, D.; Zmarzły, P.; Rudnik,

M.; Szot, W.; Szczygiel, P.; Musiałek,

M. Analysis of Metrological Quality and Mechanical Properties of Models Manufactured with Photo-Curing

PolyJet Matrix Technology for

Medical Applications. Polymers 2022,

14, 408. https://doi.org/10.3390/

polym 14030408

Academic Editor: Paweł Turek

Received: 22 December 2021

Accepted: 17 January 2022

Published: 20 January 2022

Publisher's Note: MDPI stays neutral with regard to jurisdictional claims in published maps and institutional affiliations.

Copyright: (C) 2022 by the authors. Licensee MDPI, Basel, Switzerland. This article is an open access article distributed under the terms and conditions of the Creative Commons Attribution (CC BY) license (https:// creativecommons.org/licenses/by/ $4.0 /)$.
Faculty of Mechatronics and Mechanical Engineering, Kielce University of Technology, 25-314 Kielce, Poland; jbochnia@tu.kielce.pl (J.B.); dgogolewski@tu.kielce.pl (D.G.); pzmarzly@tu.kielce.pl (P.Z.); mrudnik@tu.kielce.pl (M.R.); wszot@tu.kielce.pl (W.S.); pszczygiel@tu.kielce.pl (P.S.); mmusialek@tu.kielce.pl (M.M.)

* Correspondence: tkozior@tu.kielce.pl; Tel.: +48-41-3424453

Abstract: This paper presents the metrological quality and mechanical properties of models in the form of hook holders manufactured from MED610 polymer material using PolyJet Matrix (PJM) technology. Measurements in the dimensional and shape analysis were made using the optical method with a microscope. The mechanical test was estimated by static tensile testing of the fabricated parts. A comprehensive approach to both the analysis of test results based on standardized samples and real hook models makes the presented results of great scientific and engineering value and creates the possibility of practical use in the medical industry, which has not been so comprehensively presented in the currently published research papers. Analyzing the results of measurements of the geometrical characteristics of the elements, it can be concluded that the PolyJet Matrix 3D printing technology has demonstrated a high level of precision in manufacturing the prototype parts. The static tensile test of samples, taking into account the printing directions, showed a high anisotropy of mechanical properties. The results of both strength and simulation tests indicate that it is necessary to assume a relatively high safety factor, the value of which depends on the direction of printing, which, in the case of such a responsible medical application, is very important.

Keywords: PJM; MED610; mechanical properties; metrological quality; 3D printing

\section{Introduction}

With the development of industry, the use of additive technologies has become increasingly common. Three-dimensional printing technologies are one of the areas that significantly contribute to the development of science, including medical sciences. Innovations in the field of medical science using 3D printing concern components and assemblies as well as the materials from which they are made. A wide range of materials, i.e., plastics, biomedical materials, ceramics and metals, are kinds of semi-finished products in 3D printing and are used for printing [1-8]. Initially, 3D printing was used for prototyping. Recently, however, 3D printing technology has gained great interest in many areas of production of components, including cylindrical ones $[9,10]$. It is known as additive manufacturing, which builds physical objects by applying successive layers of material of a specified thickness using a printer-understandable code generated by a so-called Slicer [11-13]. Compared to traditional component manufacturing methods, the ability to 3D print widens the possibilities for design, modification of a designed component, and visualization [14]. Rapid prototyping is supported by reverse engineering and has applications in the field of medical science. It enables rapid prototyping of individually adapted dimensions of a prosthesis to a patient and his/her disease. More and more often in medical applications, a 
combination of several technologies is used, such as 3D printing and electrospinning [15], where the PJM technology has a very large potential application [16].

The analysis of the literature and the preliminary results of our research have shown that the print direction is one of the key parameters influencing the mechanical and tribological [17] properties as well as the dimensional and shape accuracy of the models produced; therefore, in the presented work, the sample models were made in several different locations on the building platform.

The production of models from biomedical materials is accompanied by Polyjet Matrix (PJM) printers, the principle of which is as follows: the printing heads spray the material layer by layer onto the platform, which is cured by ultraviolet light [18-20]. This technology is very precise and applied due to the types of materials used. Prototypes should be prepared in advance, i.e., if multicolored fragments of the model are used, appropriate STL files should be prepared separately and the entire project should be exported as OBJ/VRML files [21]. The printing speed and precision depend on the choice of one of three modes, i.e., high quality, high speed and digital material. Models made with PolyJet Matrix technology use additional material for support structures. They are formed by a separate group of heads, which can be removed using pressure washers, solutions or mechanical separation using water $[22,23]$.

This work presents a model of a medical robot's hook holder made of MED 610 material, which, suitably adapted, could serve as part of the manipulator in the medical robot used in surgical operations for direct interaction with the human body. Its rounded working surface and design are adapted to move and hold small veins or tissues so that they are not damaged [24]. The medical robot enables not only the visualization of the surgical field in a three-dimensional image through tenfold magnification. It also enables making incisions, supporting and moving tissues and burning them. It further reduces human factors in the form of hand tremors and imprecision in some surgeons [24-26]. The robot's hook holder, made of a biocompatible polymer with living tissue, appears to be more natural than a rigid handle made of stainless steel. However, it must meet the appropriate strength and geometric requirements.

New additive solutions are entering the industrial application space as 3D printing evolves. One such application is robotics, which in combination with 3D printing, is the future of intelligent robots. By designing in $\mathrm{CAD}$, designers can tailor the robot to their specific needs. This provides the freedom to add new features to the models. The 3D printing allows designers to forget about the current limitations resulting from the use of conventional manufacturing methods and open up new possibilities. It allows the robot arm to be better adapted and optimized to different operational requirements $[27,28]$. Medical robots designed to perform medical operations usually do not work independently but support medical personnel, increasing the precision and quality of their work [29].

Based on a preliminary review of the literature, it can be concluded that additive technology is starting to become increasingly important in the medical field. The growing importance of 3D printing in medicine is accompanied by the development of biocompatible materials. Therefore, it seems reasonable to carry out research into, among other things, mechanical strength. This paper describes the results of testing the dimension and shape precision and mechanical strength in the potential application of hook-holder models intended for use in the medical robot.

\section{Materials and Methods}

\subsection{PJM Technology}

Test samples were prepared using a machine Connex 350 (Stratasys corp. Rehovot, Israel), which is the high photo-curable liquid polymer resin PolyJet Matrix (PJM). The samples were made in high quality mode. This makes it possible to make models that are impossible to produce by using conventional technologies, e.g., cell structures. The implementation of models with cellular structures in different orientations using 3D printing technology may affect the strength properties of the structures. The PolyJet Matrix technol- 
ogy is characterized by the continuous application of material from various groups of print heads. This process, in contrast to other technology, eliminates the need for re-exposure after the printing element. PolyJet Matrix technology allows you to work in three modes:

- $\quad$ High speed (HS) — with a material layer height of $32 \mu \mathrm{m}$, which is characterized by high-speed printing parts;

- High quality (HQ) — with a material layer height of $16 \mu \mathrm{m}$, which is characterized by a lower print speed and very high accuracy;

- Digital material (DM) — with a material layer height of $32 \mu \mathrm{m}$, which is characterized by the combination of different materials.

\subsection{Material MED610}

MED610 (Stratasys corp. Rehovot, Izrael) is a biocompatible material used in PolyJet printing technology for medical and dental applications. The manufacturer states that the material may remain permanently in contact with the skin (more than 30 days) and for a limited time in contact with the oral mucous membrane (up to $24 \mathrm{~h}$ ). The material has been developed in accordance with accepted standards taking into account: cytotoxicity (EN ISO 10993-5:2009) [30], irritation and hypersensitivity type IV (EN ISO 10993-10:2013) [31], genotoxicity (EN ISO 10993-3:2014) [32], chemical characterization (EN ISO 10993-18:2009) [33]. The characteristics are given in Table 1 together with the standard/procedure by which they are measured and with the composition, respectively, where it is presented according to percentage weights $[34,35]$.

Table 1. Properties and chemical composition of MED 610 material [34,35].

\begin{tabular}{|c|c|c|}
\hline \multicolumn{3}{|c|}{ Properties } \\
\hline Property & Standard & Value \\
\hline Tensile strength & D-638-03 & $50-65 \mathrm{MPa}$ \\
\hline Ultimate elongation & D-638-05 & $10-25 \%$ \\
\hline Young's modulus & D-638-04 & $2000-3000 \mathrm{MPa}$ \\
\hline Bending strength & D-790-03 & $75-110 \mathrm{MPa}$ \\
\hline Modulus of elasticity in bending & D-790-04 & $2200-3200 \mathrm{MPa}$ \\
\hline Poisson ratio * & ASTM D638-10 & 0.41 \\
\hline $\begin{array}{l}\text { Deflection temperature (under } \\
\text { load of } 0.46 \mathrm{MPa} \text { ) }\end{array}$ & D-648-06 & $45-50{ }^{\circ} \mathrm{C}$ \\
\hline Water absorption & D-570-98 24HR & $1.1-1.5 \%$ \\
\hline Shore hardness & D Scale & $83-85$ D \\
\hline Rockwell hardness & M Scale & $73-76 \mathrm{M}$ \\
\hline Biocompatibility & PN-EN ISO 10993-1:2017 & $\begin{array}{c}\text { Skin contact: } \\
\text { - more than } 30 \text { days } \\
\text { Contact with mucous } \\
\text { membrane: } \\
\text { - up to } 24 \mathrm{~h}\end{array}$ \\
\hline \multicolumn{3}{|c|}{ Chemical composition } \\
\hline Component & & $\%$ of weights \\
\hline Isbornyl acrylate & & $15-30$ \\
\hline Acrylic monomer & & $15-30$ \\
\hline Urethane acrylate & & $10-30$ \\
\hline Acrylic monomer & & $5-10 ; 10-15$ \\
\hline Epoxy acrylate & & $5-10 ; 10-15$ \\
\hline Arylate oligomer & & $5-10 ; 10-15$ \\
\hline Photoinitiator & & $0.1-1 ; 1-2$ \\
\hline
\end{tabular}

* Note: the Poisson ratio value was obtained by e-mail from Stratasys at the authors' request. 


\subsection{Measurement Technologies}

The measuring instruments used to measure internal and external dimensions are the MarVision MM 320 Microscope (Mitutoyo, Kawasaki, Japan) and the Mitutoyo Digital Micrometer. The Mahr microscope allows geometrical features to be measured using an integrated CCD camera. It is based on a hardened granite base together with an XY table. The CCD camera and the 0.7-4.5x Navitar Zoom lens are mounted on a stable Z column with a vertical motion of $200 \mathrm{~mm}$. A digital micrometer (Mitutoyo, Kawasaki, Japan) with a measurement resolution of $0.001 \mathrm{~mm}$ was used to measure the thickness of the A and B hook holders at four locations.

The Inspekt Mini strength testing machine from Hegewald and Peschke MPT GmbH with the LabMaster software (Hegewald and Peschke, Nossen, Germany) was used to test strength at the maximum load of $3 \mathrm{kN}$. An example of a hook holder and tensile samples during testing is shown in Figure 1. The values of the individual quantities were calculated from the following formulas [36]:

- Mean value

$$
\bar{x}=\frac{\sum_{i=1}^{n} x_{i}}{n}
$$

where: $n$-group size; $x_{i}$ - single test result

- Standard deviation

$$
S D=\sqrt{\frac{1}{(n-1)} \sum_{i=1}^{n}\left(x_{i}-\bar{x}\right)^{2}}
$$

where: $n$-group size; $x_{i}$-single test result; $\bar{x}$ - test mean value;

- Sample cross-section

$$
\text { Section }=a \cdot b
$$

where: $a$-sample width value; $b$-sample thickness value

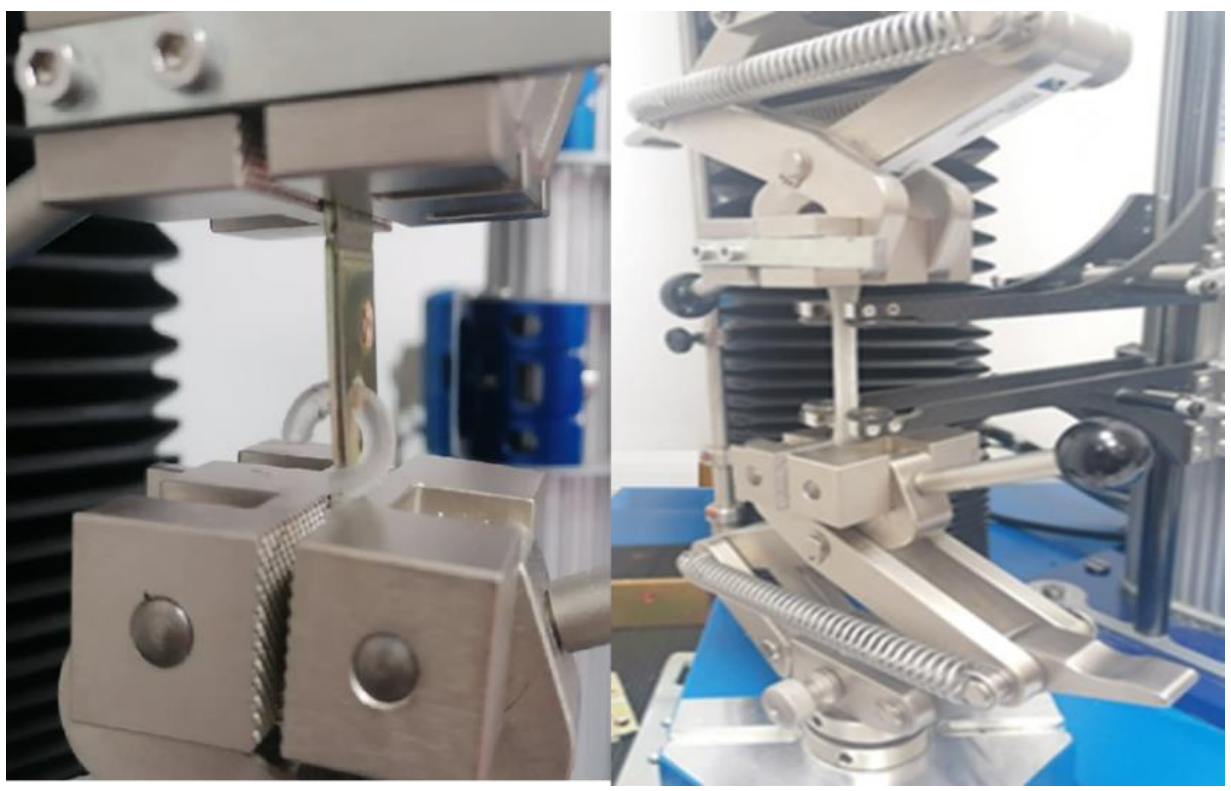

Figure 1. Tensile test of ISO 527 sample and hook holder. 


\subsection{Samples Preparation}

The hook holders for the medical robot were designed using SolidWorks software (Dassault Systemes SolidWorks Corp., Waltham, MA, USA) and saved in STL format, which gives the solid model a mesh composed of triangles. The output for the holders is binary and the units in the file are in millimeters. In order to distinguish the hook holders, they have been given symbolic designations: A-17-mm-long hook holder; B-34-mm-long hook holder. For hook holder A, a fine resolution was adopted, which gives a linear deviation of approximately $0.009 \mathrm{~mm}$ and an angle of $10^{\circ}$ (Figure 2a). For the second hook holder B, the fine resolution STL format gives a linear deviation of approximately $0.017 \mathrm{~mm}$ and an angle of $10^{\circ}$ (Figure $2 \mathrm{~b}$ ).

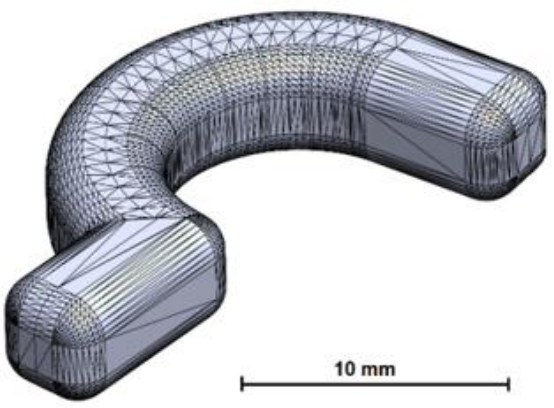

(a)

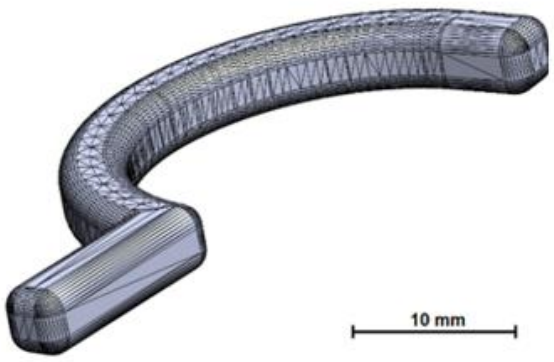

(b)

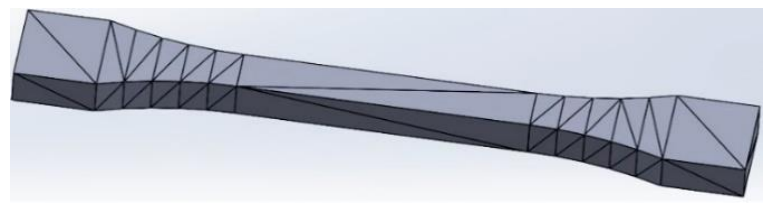

(c)

Figure 2. Samples: (a) hook holder A as an approximated triangle mesh; (b) hook holder B as an approximated triangle mesh; (c) test according to ISO 527 as an approximated triangle mesh.

Samples for the strength tests were designed in accordance with ISO 527 using SolidWorks software and saved in STL format with the options: deflection $0.0364 \mathrm{~mm}$ and angle $10^{\circ}$ (Figure 2c).

STL files of the hook-holder models and sample were placed in Objet Studio on the virtual work of the Connex 350 printer in three characteristic directions (Figure 3a). The printout was made in high quality mode in matt mode.

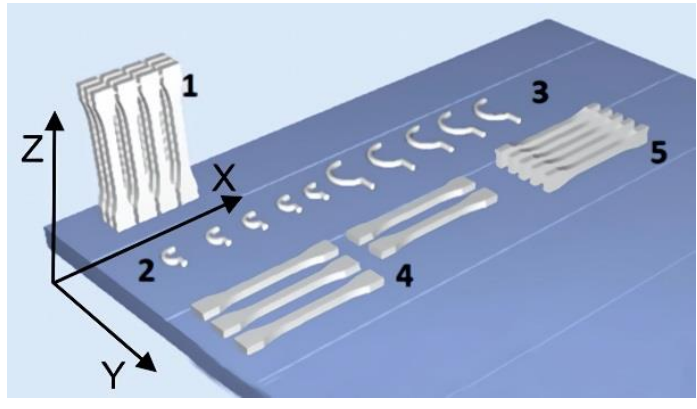

(a)

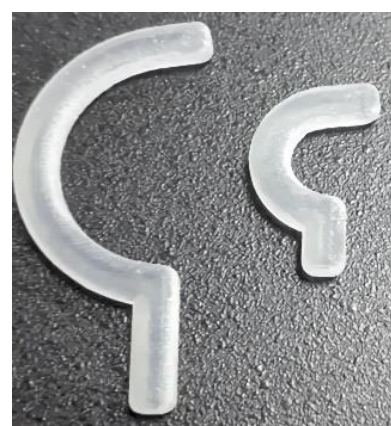

(b)

Figure 3. Samples: (a) arrangement of samples and handles on the work platform, where: (1)vertical orientation of the sample pack-OZ direction, (2)—hook holder A, (3)-hook holder B, (4)—flat setting, (5)—side setting-OX direction; (b) printed hook holders. 
The hook holders A and B (Figure 3b) are made from MED 610 (Table 1) using PJM additive technology. The print had a layer height of $0.016 \mathrm{~mm}$. In order to easily distinguish between the two types of hook holders, they are marked: A-17 mm long hook holder; B-34 mm long hook holder.

\section{Results}

\subsection{Dimensional and Shape Precision}

The number of samples used for measurement is five for each type of medical robot hook holder. Figure 4 shows the markings of the measured geometric features. Geometric features defining length and radii were marked $\mathrm{C} 1-\mathrm{C} 8$ and features defining thickness as T1-T4. Figure 4 also shows the dimensions of the hook holders A and B, which were designed using SolidWorks software. In the following analysis they will be denoted by the abbreviation CAD. Table 2 shows the results of the measurements of the A and B hook holders. In addition, basic statistics were calculated: mean value and standard deviation from formulas 1 and 2 .

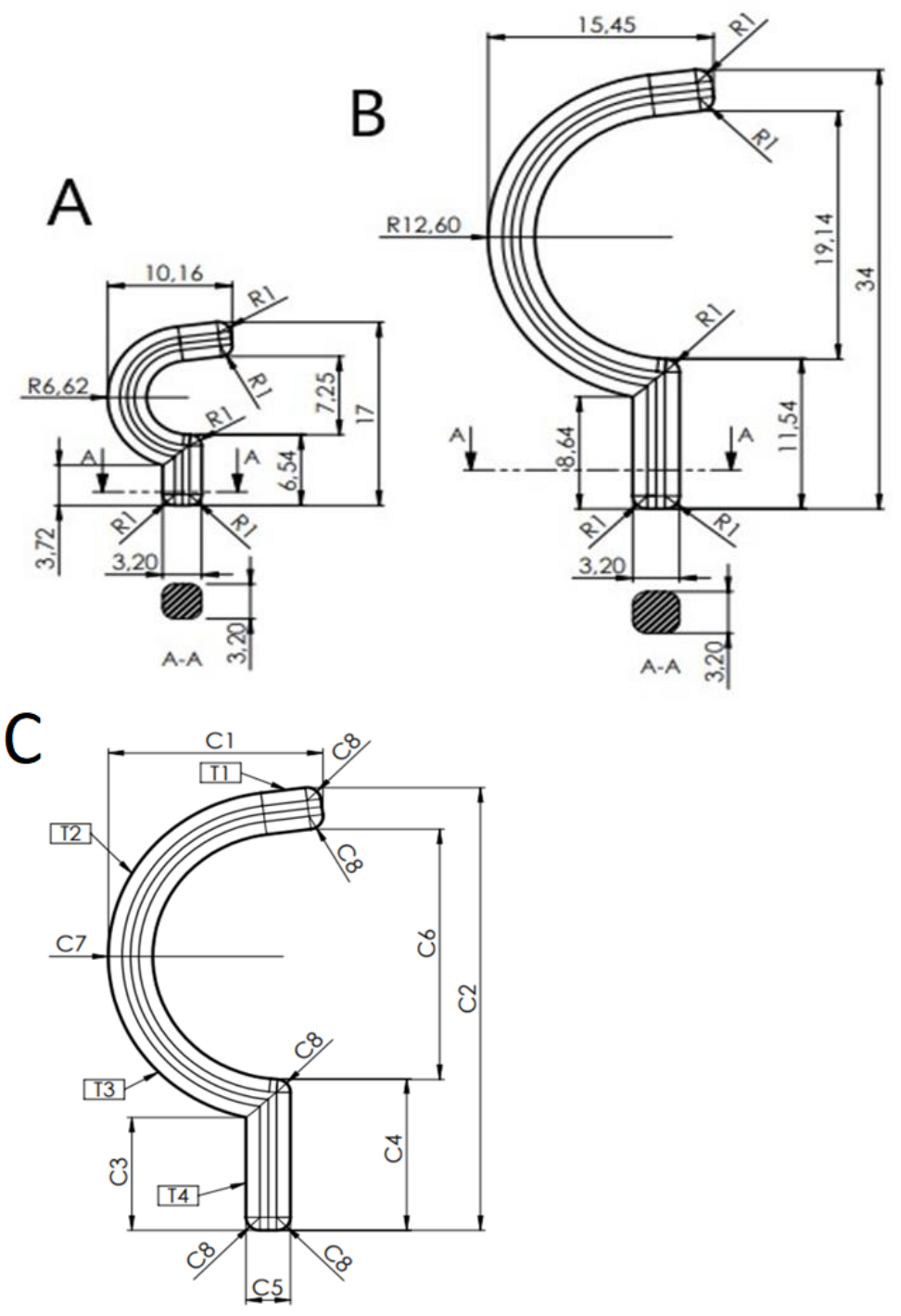

Figure 4. Geometrical characteristic of hook holder and CAD dimension of: (A) hook holder-length $17 \mathrm{~mm},(\mathbf{B})$ hook holder-length $34 \mathrm{~mm},(\mathbf{C})$ metrological features. 
Table 2. Results of measurements of geometrical features, values in $\mathrm{mm}$.

\begin{tabular}{|c|c|c|c|c|c|c|c|c|c|}
\hline \multirow{2}{*}{$\begin{array}{c}\text { Geometric } \\
\text { Characteristic and } \\
\text { Thickness }(\mathrm{mm})\end{array}$} & \multirow{2}{*}{$\begin{array}{c}\text { CAD } \\
\text { Dimensional }\end{array}$} & \multicolumn{5}{|c|}{ Samples } & \multirow{2}{*}{ Average } & \multirow[b]{2}{*}{ SD } & \multirow{2}{*}{$\begin{array}{l}\text { Hook } \\
\text { Holder }\end{array}$} \\
\hline & & 1 & 2 & 3 & 4 & 5 & & & \\
\hline $\mathrm{C} 1$ & 10.16 & 8.333 & 9.956 & 10.767 & 11.052 & 10.663 & 10.1542 & 1.095 & \multirow{12}{*}{ A } \\
\hline $\mathrm{C} 2$ & 17 & 16.945 & 17.325 & 14.766 & 13.706 & 14.637 & 15.476 & 1.575 & \\
\hline $\mathrm{C} 3$ & 3.72 & 3.795 & 3.642 & 3.799 & 3.893 & 3.807 & 3.787 & 0.091 & \\
\hline $\mathrm{C4}$ & 6.54 & 6.684 & 6.773 & 6.671 & 6.883 & 6.737 & 6.75 & 0.085 & \\
\hline $\mathrm{C} 5$ & 3.2 & 3.305 & 3.223 & 3.302 & 3.356 & 3.26 & 3.289 & 0.05 & \\
\hline $\mathrm{C} 6$ & 7.25 & 6.912 & 7.33 & 7.193 & 6.924 & 6.966 & 7.065 & 0.187 & \\
\hline $\mathrm{C7}$ & 6.62 & 6.666 & 6.642 & 6.607 & 6.580 & 6.494 & 6.598 & 0.066 & \\
\hline $\mathrm{C} 8$ & 1 & 0.949 & 1.279 & 1.205 & 1.1741 & 1.125 & 1.147 & 0.111 & \\
\hline T1 & 3.2 & 3.221 & 3.226 & 3.243 & 3.201 & 3.221 & 3.222 & 0.015 & \\
\hline $\mathrm{T} 2$ & 3.2 & 3.215 & 3.227 & 3.226 & 3.216 & 3.218 & 3.220 & 0.006 & \\
\hline T3 & 3.2 & 3.218 & 3.276 & 3.216 & 3.208 & 3.202 & 3.224 & 0.03 & \\
\hline $\mathrm{T} 4$ & 3.2 & 3.205 & 3.275 & 3.217 & 3.206 & 3.221 & 3.225 & 0.029 & \\
\hline $\mathrm{C} 1$ & 15.45 & 16.631 & 16.709 & 15.601 & 15.775 & 15.771 & 16.097 & 0.528 & \multirow{12}{*}{ B } \\
\hline $\mathrm{C} 2$ & 34 & 31.241 & 33.79 & 33.921 & 33.876 & 33.804 & 33.326 & 1.167 & \\
\hline $\mathrm{C} 3$ & 8.64 & 8.701 & 8.616 & 8.646 & 8.733 & 8.679 & 8.675 & 0.046 & \\
\hline $\mathrm{C} 4$ & 11.54 & 11.627 & 11.665 & 11.734 & 11.74 & 11.79 & 11.711 & 0.067 & \\
\hline C5 & 3.2 & 3.298 & 3.361 & 3.35 & 3.365 & 3.28 & 3.331 & 0.039 & \\
\hline C6 & 19.14 & 18.529 & 18.93 & 18.955 & 18.87 & 18.856 & 18.828 & 0.528 & \\
\hline $\mathrm{C} 7$ & 12.6 & 12.595 & 12.628 & 12.626 & 12.608 & 12.628 & 12.617 & 0.172 & \\
\hline $\mathrm{C} 8$ & 1 & 1.159 & 1.255 & 1.129 & 0.998 & 1.125 & 1.133 & 0.092 & \\
\hline T1 & 3.2 & 3.21 & 3.209 & 3.208 & 3.242 & 3.223 & 3.218 & 0.015 & \\
\hline $\mathrm{T} 2$ & 3.2 & 3.201 & 3.207 & 3.203 & 3.201 & 3.206 & 3.204 & 0.003 & \\
\hline T3 & 3.2 & 3.202 & 3.208 & 3.205 & 3.22 & 3.201 & 3.207 & 0.008 & \\
\hline $\mathrm{T} 4$ & 3.2 & 3.214 & 3.207 & 3.224 & 3.228 & 3.208 & 3.216 & 0.009 & \\
\hline
\end{tabular}

From Table 2, it can be seen that the standard deviation value was the lowest for T2 thickness and the highest standard deviation value was for the $\mathrm{C} 2$ geometric characteristic in the A hook holder. The lowest value of the standard deviation was for T2 thickness and the highest standard deviation value was for the $\mathrm{C} 2$ geometric characteristic in the $\mathrm{A}$ hook holder.

For the graphs showing the geometric values of the holders A and B (Figure 4), the following conditions were applied:

- The red line represents the CAD form, which is the value imposed by the research team to make the holder.

- The black line named, respectively, 0.1 and $-0.1 \mathrm{~mm}$ indicate the PolyJet printing precision, i.e., $0.1 \mathrm{~mm}$.

- The average CAD value columns show the difference between the mean value and the value used in the CAD drawing, i.e.,

- $\quad$ Difference $=$ average value $-\mathrm{CAD}$ value (4).

- Where the difference between the values will be represented as a mean value. The columns show how the mean value deviates from the given CAD dimension.

- The brown, red, blue, black and orange colored points represent the geometrical characteristics $\mathrm{C} 1-\mathrm{C} 8$ and $\mathrm{T} 1-\mathrm{T} 4$ for the measured holder. 
These values are the result of the difference between the value of the sample number for the relevant characteristic and the value adopted in the CAD drawing. If the columns and points take positive/negative values, it means that the characteristics deviate from the value imposed in the holder design.

\subsection{Metrological Analysis}

Tables 3 and 4 show the geometric quality of printed elements.

Table 3. Geometric features of hook holder A and B.

\begin{tabular}{|c|c|c|c|c|c|c|c|c|}
\hline \multicolumn{9}{|c|}{ Hook Holder A } \\
\hline & $\begin{array}{c}\mathrm{C} 1 \\
(\mathrm{~mm})\end{array}$ & $\begin{array}{c}\mathrm{C} 2 \\
(\mathrm{~mm})\end{array}$ & $\begin{array}{c}\mathrm{C} 3 \\
(\mathrm{~mm})\end{array}$ & $\begin{array}{c}\mathrm{C} 4 \\
(\mathrm{~mm})\end{array}$ & $\begin{array}{c}\mathrm{C} 5 \\
(\mathrm{~mm})\end{array}$ & $\begin{array}{c}\mathrm{C} 6 \\
(\mathrm{~mm})\end{array}$ & $\begin{array}{c}\mathrm{C} 7 \\
(\mathrm{~mm})\end{array}$ & $\begin{array}{c}\mathrm{C} 8 \\
(\mathrm{~mm})\end{array}$ \\
\hline A1 & -1.827 & -0.055 & 0.075 & 0.144 & 0.105 & -0.338 & 0.046 & -0.051 \\
\hline A2 & -0.204 & 0.325 & -0.078 & 0.233 & 0.023 & 0.08 & 0.022 & 0.279 \\
\hline A3 & 0.607 & -2.234 & 0.079 & 0.131 & 0.102 & -0.057 & -0.013 & 0.205 \\
\hline A4 & 0.892 & -3.294 & 0.173 & 0.343 & 0.156 & -0.326 & -0.04 & 0.174 \\
\hline A5 & 0.503 & -2.363 & 0.087 & 0.197 & 0.06 & -0.284 & -0.126 & 0.125 \\
\hline $\begin{array}{c}\text { Difference } \\
\text { (mean value) }\end{array}$ & -0.006 & -1.524 & 0.067 & 0.21 & 0.089 & -0.185 & -0.022 & 0.147 \\
\hline \multicolumn{9}{|c|}{ Hook Holder B } \\
\hline & $\begin{array}{c}\mathrm{C} 1 \\
(\mathrm{~mm})\end{array}$ & $\begin{array}{c}\mathrm{C} 2 \\
(\mathrm{~mm})\end{array}$ & $\begin{array}{c}\mathrm{C} 3 \\
(\mathrm{~mm})\end{array}$ & $\begin{array}{c}\mathrm{C} 4 \\
(\mathrm{~mm})\end{array}$ & $\begin{array}{c}\mathrm{C} 5 \\
(\mathrm{~mm})\end{array}$ & $\begin{array}{c}\mathrm{C} 6 \\
(\mathrm{~mm})\end{array}$ & $\begin{array}{c}\mathrm{C} 7 \\
(\mathrm{~mm})\end{array}$ & $\begin{array}{c}\mathrm{C} 8 \\
(\mathrm{~mm})\end{array}$ \\
\hline B1 & 1.181 & -2.759 & 0.061 & 0.087 & 0.098 & -0.611 & -0.005 & 0.159 \\
\hline B2 & 1.259 & -0.21 & -0.024 & 0.125 & 0.161 & -0.21 & 0.028 & 0.255 \\
\hline B3 & 0.151 & -0.079 & 0.006 & 0.194 & 0.15 & -0.185 & 0.026 & 0.129 \\
\hline B4 & 0.325 & -0.124 & 0.093 & 0.2 & 0.165 & -0.27 & 0.0078 & -0.002 \\
\hline B5 & 0.321 & -0.196 & 0.039 & 0.25 & 0.08 & -0.284 & 0.028 & 0.125 \\
\hline $\begin{array}{c}\text { Difference } \\
\text { (mean value) }\end{array}$ & 0.647 & -0.674 & 0.035 & 0.171 & 0.131 & -0.312 & 0.017 & 0.133 \\
\hline
\end{tabular}

The values of geometrical feature $\mathrm{C} 1$ indicate that only one value is around the print precision boundary, i.e., for the holder A2; however, it is $0.1 \mathrm{~mm}$ away from the imposed guideline. Other features are concentrated far from the set boundaries. There is also a large gap between the minimum and maximum values. A similar situation occurs for feature C2; however, for the holder A1 the value is almost in the middle of the -0.1 to 0 range. For feature $\mathrm{C} 3$, the four values are between -0.1 and $0.1 \mathrm{~mm}$. The results of the $\mathrm{C} 4$ feature measurements are located above the $0.1 \mathrm{~mm}$ limit. Excluding the A4 holder measurement value, the rest of the value oscillates around the mean value. For the $C 5$ feature, the values oscillate between 0 and $0.1 \mathrm{~mm}$.

Excluding the holder A4, each value is around the measurement precision. The values for feature $\mathrm{C} 6$ are for the holder $\mathrm{A} 2$ in the range $0-0.1 \mathrm{~mm}$ and $\mathrm{A} 3$ in the range $-0.1 \mathrm{~mm}-0$. The other values of this feature oscillate around each other without exceeding the precision of PJM printing. For feature C7, it can be observed that only one of the values for the holder A5 exceeds the imposed printing precision; however, each of the other values oscillates around the CAD dimension. For feature C8, it can be observed that most of the measurement values are around the upper limit of printing precision. The exception is the A1 holder feature, which is almost in the middle of the $0.1 \mathrm{~mm}-0$ range. In the case of features $\mathrm{C} 1, \mathrm{C} 3$ and $\mathrm{C} 5$, the mean value is within the limits of the part printing precision with the PJM additive technology. For features $\mathrm{C} 1, \mathrm{C} 2, \mathrm{C} 6$ and $\mathrm{C} 7$, the mean shows negative values for various reasons. In the case of feature $\mathrm{C} 1$, it is a single dimension that has a 
significant effect on the result, and in the case of features C2, C6, C7 there are negative values of dimensions that have a significant effect on the mean value. For feature $\mathrm{C} 6$ the values are in the 1:4 ratio, where the negative values are clustered against each other. In the case of feature $\mathrm{C}$, the mean values are 2:3 (Table 3, Figure 5).

Table 4. Thickness of hook holder A and B.

\begin{tabular}{|c|c|c|c|c|}
\hline \multicolumn{5}{|c|}{ Hook Holder A } \\
\hline & $\begin{array}{c}\mathrm{T} 1 \\
(\mathrm{~mm})\end{array}$ & $\begin{array}{c}\mathrm{T} 2 \\
(\mathrm{~mm})\end{array}$ & $\begin{array}{c}\mathrm{T} 3 \\
(\mathrm{~mm})\end{array}$ & $\begin{array}{c}\mathrm{T} 4 \\
(\mathrm{~mm})\end{array}$ \\
\hline A1 & 0.021 & 0.015 & 0.018 & 0.005 \\
\hline A2 & 0.026 & 0.027 & 0.076 & 0.075 \\
\hline A3 & 0.043 & 0.026 & 0.016 & 0.017 \\
\hline A4 & 0.001 & 0.016 & 0.008 & 0.006 \\
\hline A5 & 0.021 & 0.018 & 0.002 & 0.021 \\
\hline $\begin{array}{c}\text { Difference } \\
\text { (mean value) }\end{array}$ & 0.023 & 0.02 & 0.024 & 0.025 \\
\hline \multicolumn{5}{|c|}{ Hook Holder B } \\
\hline & $\begin{array}{c}\mathrm{T} 1 \\
(\mathrm{~mm})\end{array}$ & $\begin{array}{c}\mathrm{T} 2 \\
(\mathrm{~mm})\end{array}$ & $\begin{array}{c}\mathrm{T} 3 \\
(\mathrm{~mm})\end{array}$ & $\begin{array}{c}\mathrm{T} 4 \\
(\mathrm{~mm})\end{array}$ \\
\hline B1 & 0.01 & 0.001 & 0.002 & 0.014 \\
\hline B2 & 0.009 & 0.007 & 0.008 & 0.007 \\
\hline B3 & 0.008 & 0.003 & 0.005 & 0.024 \\
\hline B4 & 0.042 & 0.001 & 0.02 & 0.028 \\
\hline B5 & 0.023 & 0.006 & 0.001 & 0.008 \\
\hline $\begin{array}{c}\text { Difference } \\
\text { (mean value) }\end{array}$ & 0.018 & 0.004 & 0.007 & 0.016 \\
\hline
\end{tabular}

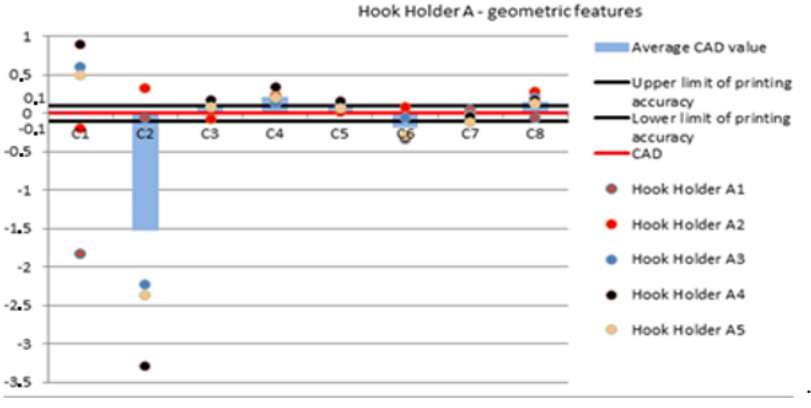

(a)

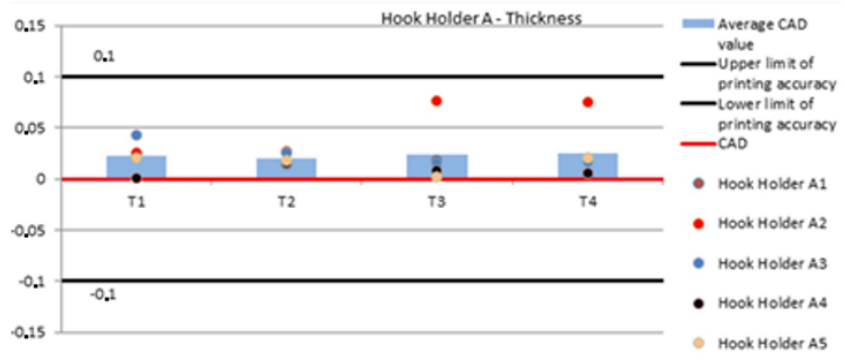

(b)

Figure 5. Geometric features (a) and thickness (b) of hook holder A.

For feature $\mathrm{C} 1$, all points are concentrated outside the printing precision limit. The closest to this limit is the feature for the B3 holder. It can also be observed that the values of this feature for the B4 and B5 holders are close to each other, while models B1 and B2 show a high deviation from the value assumed in the CAD design. For the $\mathrm{C} 2$ feature, values are around the lower limit of printing precision. However, only the B3 model is in the -0.1 $\mathrm{mm}-0$ range. The values of $\mathrm{B} 4$ and $\mathrm{B} 5$ are outside the range, with feature $\mathrm{C} 2$ for model $\mathrm{B} 5$ being almost $0.1 \mathrm{~mm}$ away from the assuming limits. For feature $\mathrm{C} 3$, each measurement value is in the range $-0.1-0.1 \mathrm{~mm}$. For feature $\mathrm{C} 4$, only model $\mathrm{B} 1$ has a value within the mentioned range. The values for the models B3-B5 are around the $0.2 \mathrm{~mm}$ value. The C5 features for each of the hook holders are located around the upper precision limit, but only 
$\mathrm{B} 1$ and $\mathrm{B} 5$ are in the $0-0.1 \mathrm{~mm}$ range. For each of the holders, the $\mathrm{C} 6$ feature is smaller than the assumed CAD model, and none of them are in the assumed range. The values of feature C7 compared to the others are furthest from the assumed limits and closest to the values assumed in the CAD model. For feature $C 8$, the closest to the assumed value in the CAD model is the feature in part B4. The feature values for the other details are outside the designated range. The average deviations from the $C A D$ values take a negative value only twice. For feature $\mathrm{C} 2$, the value for part $\mathrm{B} 1$ plays a significant role. A different situation occurs with the $\mathrm{C} 6$ feature, where it can be observed that the dimensions are smaller than assumed (Table 3, Figure 6).

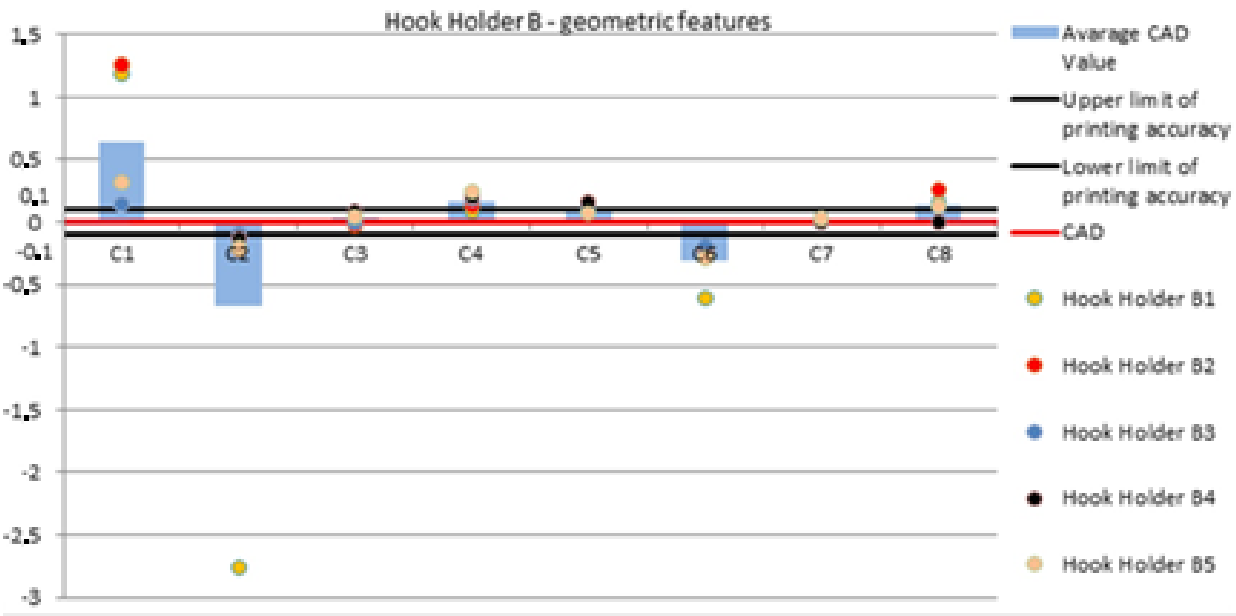

(a)

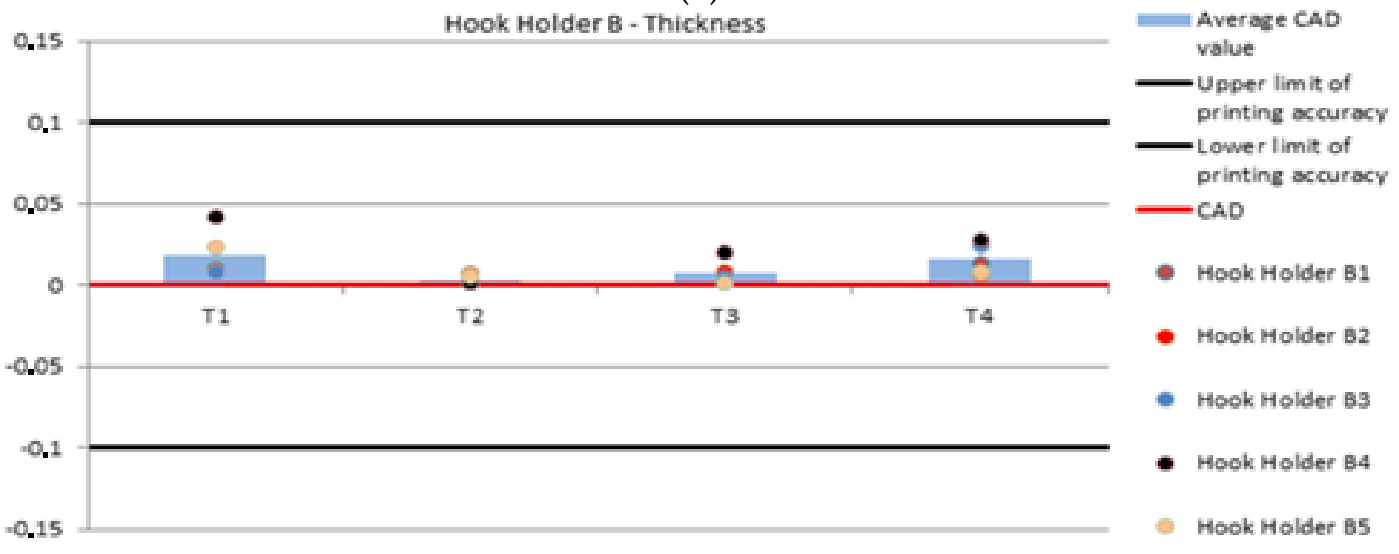

(b)

Figure 6. Geometric features (a) and thickness (b) of hook holder B.

The thickness of the A1-A5 holders is not beyond the limits of 3D printer precision. For each of the thicknesses, the values are higher than designed and are within the range of $0-0.1 \mathrm{~mm}$. The values are divergent, but the mean value of each space on the handle is similar (Table 4, Figure 5).

The thickness for the holders B1-B5 shows greater precision than for the holders A1-A5. The largest deviation is the T1 measurement value for the B4 holder. The smallest deviations from the CAD value occur sequentially for the features: for T1, the smallest deviation occurs with model B3. The feature T2 shows the lowest value in the models B1 and B4. At feature T3, model B5 shows the highest precision, and at T4, model B2 (Table 4, Figure 6). 
This section may be divided by subheadings. It should provide a concise and precise description of the experimental results, their interpretation, and the experimental conclusions that can be drawn.

\subsection{Mechanical Strength}

The static tensile test of the hook holders of the medical robot was performed using an Inspekt Mini strength testing machine with Labmaster software. Tests were performed on five pieces of holders of each type: $A$ and $B$. The values of the maximum tensile force were determined. The results of the tensile tests on the hook holder models are shown in Table 5.

Table 5. Test results of hook holder.

\begin{tabular}{|c|c|c|c|}
\hline Test Number & $\begin{array}{c}\text { Cross-Section } \\
(\mathrm{mm})\end{array}$ & $\begin{array}{l}\text { Maximum Load } \\
\qquad F_{m_{i}}(\mathrm{~N})\end{array}$ & Hook Holder \\
\hline 1 & \multirow{5}{*}{10.24} & 36.8 & \multirow{7}{*}{$\mathbf{A}$} \\
\hline 2 & & 45.7 & \\
\hline 3 & & 27.3 & \\
\hline 4 & & 46.3 & \\
\hline 5 & & 49.1 & \\
\hline \multicolumn{2}{|c|}{$\bar{x}$} & 41.1 & \\
\hline \multicolumn{2}{|c|}{$S D$} & 8.95 & \\
\hline 1 & \multirow{5}{*}{10.24} & 46.3 & \multirow{7}{*}{ B } \\
\hline 2 & & 48.9 & \\
\hline 3 & & 43.8 & \\
\hline 4 & & 30.2 & \\
\hline 5 & & 40.0 & \\
\hline \multicolumn{2}{|c|}{$\bar{x}$} & 41.8 & \\
\hline \multicolumn{2}{|c|}{$S D$} & 7.3 & \\
\hline
\end{tabular}

From Table 5, it can be observed that the mean value of the maximum load force for the hook holder $\mathrm{B}$ is $1.85 \%$ greater than the mean value of the maximum force for the hook holder A.

The standard deviation values for the measured maximum force for both types of hook holders can be considered quite large. For the holder $\mathrm{A}$, the ratio of the standard deviation to the mean value of the maximum force was $21.8 \%$, while for the holder $\mathrm{B}$ it was $17.4 \%$. This means that the measured values are very far from the mean value. The standard deviation of the measured maximum force for the hook holder A was $22.67 \%$ greater than the standard deviation for the hook holder B.

Figure 7 shows the tensile curves of the load force-elongation (load-displacement) relationship for the hook holders A and B.

Bursting of the hook holders occurred at elongation: in the range from 1 to $5.5 \mathrm{~mm}$ for the holders A (Figure 7a); in the range from 4.5 to $12 \mathrm{~mm}$ for the holders B (Figure $7 \mathrm{~b}$ ).

Table 6 shows the tensile results of the samples. The table includes the test number, the cross-section calculated from formula 4, the maximum force, the tensile strength and the printing direction of the samples. 


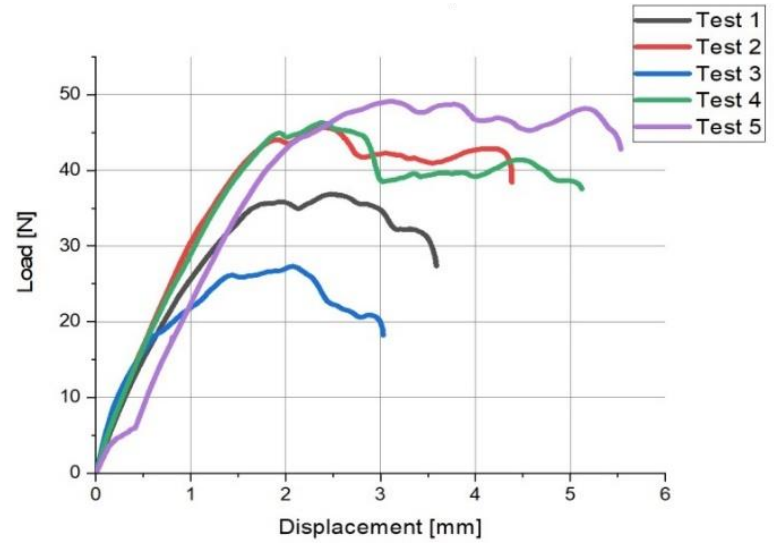

(a)

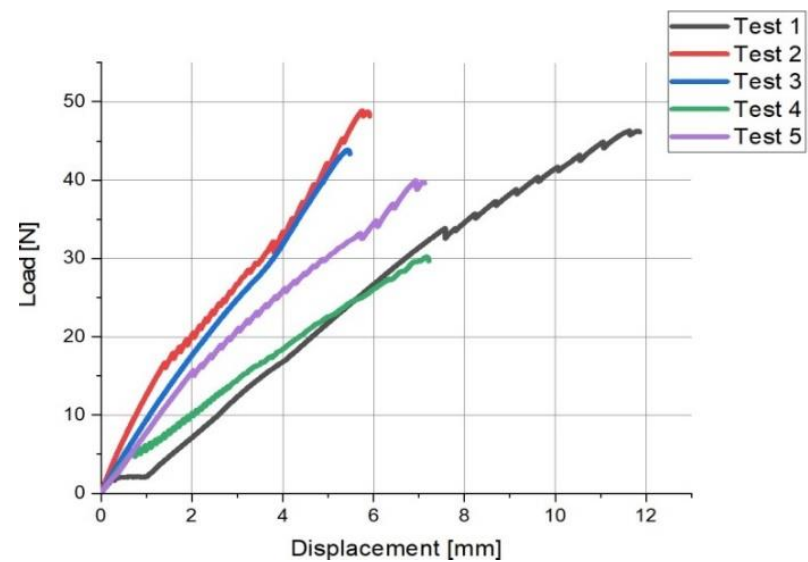

(b)

Figure 7. Tensile charts for: (a) hook holder A, (b) hook holder B.

Table 6. Tensile test results of samples ISO 527.

\begin{tabular}{|c|c|c|c|c|}
\hline Test Number & $\begin{array}{l}\text { Cross Section of } \\
\text { Sample S }\left(\mathrm{mm}^{2}\right)\end{array}$ & $\begin{array}{c}\text { Maximum } \\
\text { Strength } F_{m_{i}}(\mathrm{~N})\end{array}$ & $\begin{array}{c}\text { Tensile Strength } \\
\boldsymbol{R}_{m_{i}}(\mathrm{MPa})\end{array}$ & Axis \\
\hline 1 & \multirow{5}{*}{20.0694} & 1045.7 & 52.11 & \multirow{7}{*}{ OX } \\
\hline 2 & & 1051.7 & 52.40 & \\
\hline 3 & & 1061.4 & 52.89 & \\
\hline 4 & & 1025.2 & 51.08 & \\
\hline 5 & & 1051.4 & 52.39 & \\
\hline \multicolumn{2}{|c|}{$\bar{x}$} & 1047.08 & 52.17 & \\
\hline \multicolumn{2}{|c|}{$S D$} & 13.48 & 0.67 & \\
\hline 1 & \multirow{5}{*}{19.9796} & 967.0 & 48.40 & \multirow{7}{*}{ OY } \\
\hline 2 & & 1008.5 & 50.48 & \\
\hline 3 & & 1014.3 & 50.77 & \\
\hline 4 & & 964.6 & 48.28 & \\
\hline 5 & & 988.2 & 49.46 & \\
\hline \multicolumn{2}{|c|}{$\bar{x}$} & 988.51 & 49.48 & \\
\hline \multicolumn{2}{|c|}{$S D$} & 22.90 & 1.15 & \\
\hline 1 & \multirow{5}{*}{21.3725} & 372.8 & 17.4 & \multirow{7}{*}{$\mathrm{OZ}$} \\
\hline 2 & & 320.3 & 15.0 & \\
\hline 3 & & 384.4 & 18.0 & \\
\hline 4 & & 314.3 & 14.7 & \\
\hline 5 & & 318.4 & 14.9 & \\
\hline \multicolumn{2}{|c|}{$\bar{x}$} & 342.04 & 16.00 & \\
\hline \multicolumn{2}{|c|}{$S D$} & 33.68 & 1.58 & \\
\hline
\end{tabular}


By analyzing Table 6, it can be observed that the largest cross-section was that of the sample printed in the direction of the OZ axis: $21.3725 \mathrm{~mm}^{2}$. The sample printed in the OY direction had the smallest cross-section: $19.9796 \mathrm{~mm}^{2}$.

The highest mean maximum force occurred for the sample printed in the direction of the OX axis: $1047.08 \mathrm{~N}$. In contrast, the lowest mean maximum force was achieved by the sample printed in the OZ direction: 342 N. The highest mean maximum force was $206.13 \%$ greater than the lowest mean maximum force. The mean value of the maximum force of the printed sample in the direction of the OY axis was $189.01 \%$ greater than the lowest value of the maximum force. However, the value of the mean maximum force of the sample printed in the OX direction was 5.94\% higher than the mean maximum force for the sample printed in the OY direction.

The highest mean tensile strength value occurred for the sample printed in the OX direction and was $226.01 \%$ higher than the lowest mean tensile strength value found for the OZ sample. The mean tensile strength of the printed sample in the OY direction was $209.16 \%$ higher than the lowest value of the mean tensile strength.

The mean tensile strength of the sample printed in the OX direction was $5.45 \%$ higher than the mean tensile strength of the sample printed in the OY direction.

The ratio of the standard deviation to the mean of the maximum tensile force was:

- For the printing direction OX-1.29\%,

- For the printing direction OY-2.32\%,

- $\quad$ For the printing direction OZ-9.84\%.

The ratio of the standard deviation to the mean tensile strength was, in percentage terms, the same as the ratio of the standard deviation to the mean maximum tensile strength, which is obvious. It is clear that the greatest dispersion of results of both maximum tensile force and tensile strength occurred for samples printed in the direction of $\mathrm{OZ}$, that is, in the vertical direction.

Figure 8 shows the tensile-strain curves of ISO 527 samples. Based on the charts (Figure 8), a small dispersion of test results can be observed. It is also worth noting that the samples printed in the OX direction reached the values of the highest stress according to the chart (Figure 8a) in the range: (51-54) MPa at a strain of (9-10)\%. Samples printed in the OY direction reached values of the highest stress according to the chart (Figure $8 \mathrm{~b}$ ) in the range: $(45 ; 52) \mathrm{MPa}$ for strain in the range: $(8.8 ; 10) \%$. For samples printed in the OZ axis, the highest stress values according to the chart (Figure $8 \mathrm{c}$ ) were in the range: (14-18) $\mathrm{MPa}$ at a strain of $(3.5 ; 4.5) \%$.

The breaking of the samples occurred in ranges of strain percentages:

- OX in the range $(11.9 ; 14.5) \%$ Figure $8 \mathrm{a}$,

- OY in the range $(9.8 ; 14) \%$ Figure $8 b$,

- $\quad$ OZ in the range $(3.3 ; 4.5) \%$ Figure $8 c$. 


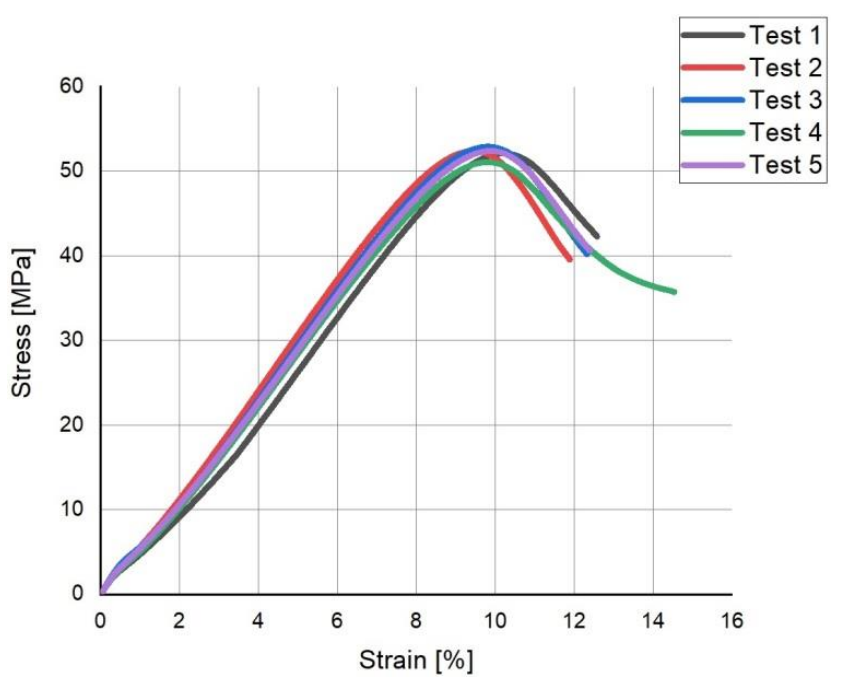

(a)

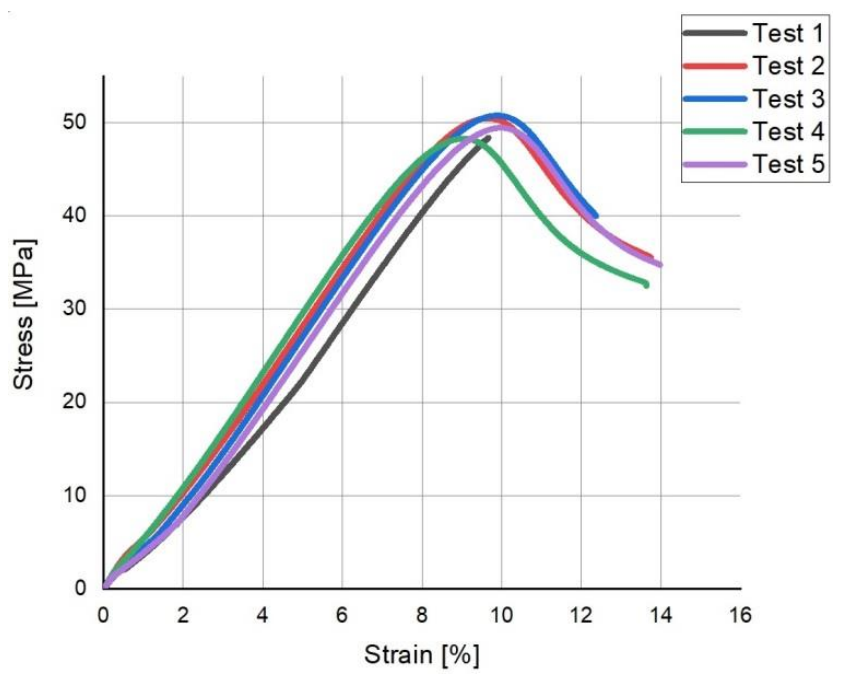

(b)

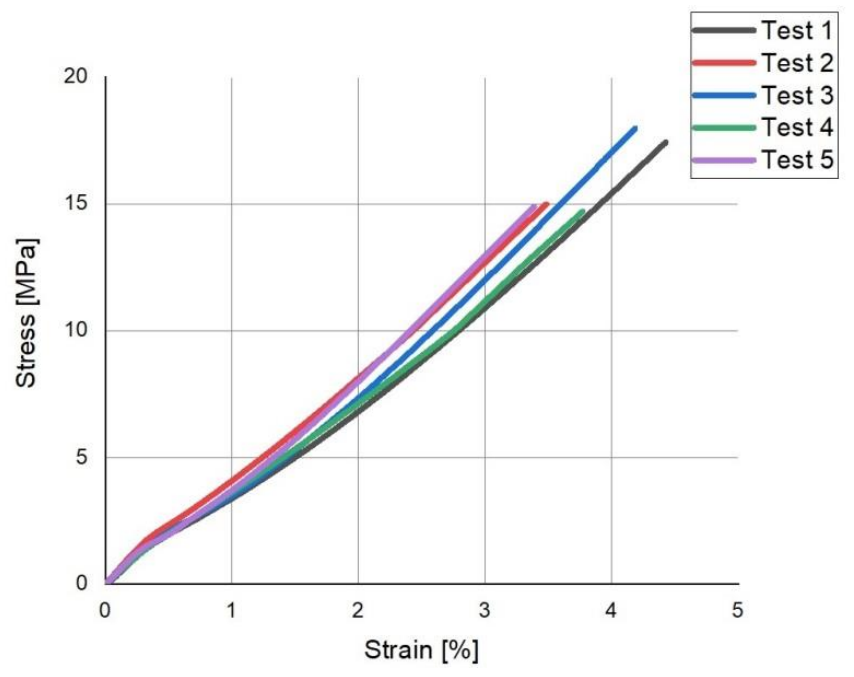

(c)

Figure 8. Samples axis: (a) OX, (b) OY, (c) OZ.

\subsection{Solidworks Simulation}

The simulation was performed to show the critical areas of the hook holder structure where the highest stresses due to tensile force occur. The results were calculated assuming a viscoelastic body model for the material data in Table 1 . The maximum force was $40 \mathrm{~N}$. Two types of simulations were performed for both hooks, where the changed test parameter was the size of the mesh. Figure $9 a, b$ shows the simulation results for models with a mesh with the same size as a single element, respectively, 0.301 and $0.377 \mathrm{~mm}$. In the case of the models presented in Figure $9 \mathrm{c}, \mathrm{d}$, the mesh retained the previous values of a single element, but at the place of its internal radius, its density was applied, where individual elements in these places were characterized by the following sizes: small hook $-0.135 \mathrm{~mm}$ and large hook $0.169 \mathrm{~mm}$. The type of mesh, the method of applying the external force and the result of the simulation calculations for the B and A hook holders are shown in Figure 9. The parameters of the generated meshes for both types of samples are presented in Table 7. 


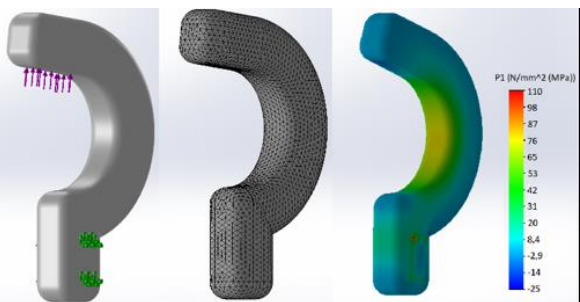

(a)

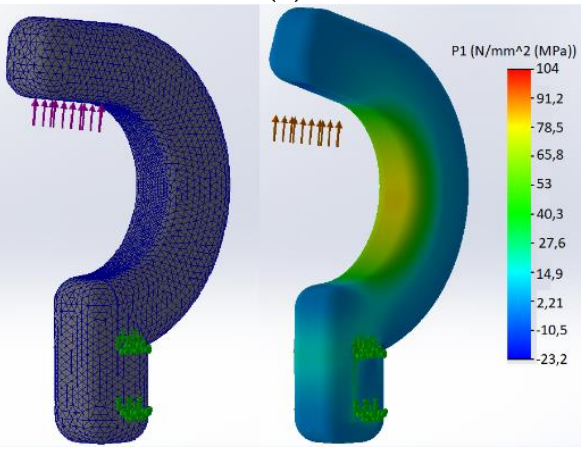

(c)

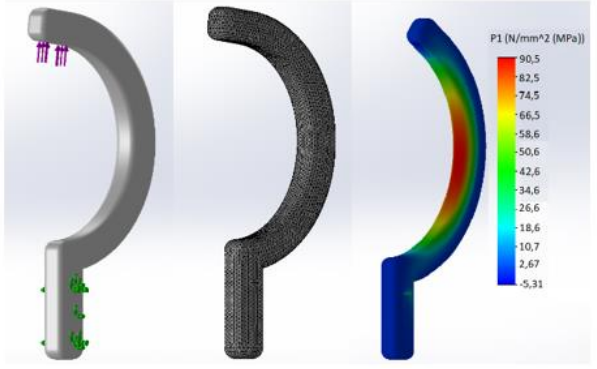

(b)

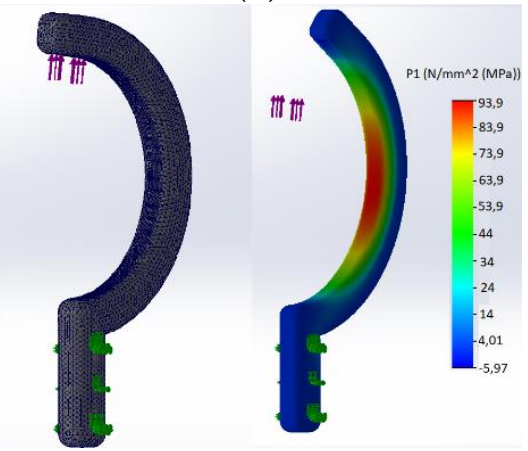

(d)

Figure 9. The mesh used, the load and the simulation result for: (a) hook holder A-mesh not densified, (b) hook holder B-mesh not densified, (c) hook holder A-mesh densified, (d) hook holder B-mesh densified.

Table 7. Mesh parameters.

\begin{tabular}{ccccc}
\hline & $\begin{array}{c}\text { Hook A } \\
\text { (Numbers of } \\
\text { Nodes) }\end{array}$ & $\begin{array}{c}\text { Hook A } \\
\text { (Numbers of } \\
\text { Triangles) }\end{array}$ & $\begin{array}{c}\text { Hook B } \\
\text { (Numbers of } \\
\text { Nodes) }\end{array}$ & $\begin{array}{c}\text { Hook B } \\
\text { (Numbers of } \\
\text { Triangles) }\end{array}$ \\
\hline $\begin{array}{c}\text { Mesh (not } \\
\text { densified) }\end{array}$ & 75,912 & 52,073 & 106,484 & 73,162 \\
\hline Mesh densified & 107,395 & 74,441 & 150,692 & 104,287 \\
\hline
\end{tabular}

From the simulations presented, it appears that the concentration of stresses occurs on the inner part of the arc of the hook holder. For mesh (not densified), the A-hooks were about $70 \mathrm{MPa}$, and for the B-hooks, $90.5 \mathrm{MPa}$. For mesh (densified), the A-hooks were about $80 \mathrm{MPa}$ and, for B-hooks, $93.9 \mathrm{MPa}$. Stresses are local in nature, causing the material to lose local cohesion, which progresses gradually into the material leading to the final break, which is also confirmed by the shape of the tensile charts of the individual hook holder models (Figure 9).

\section{Discussion}

Analyzing the results of the hook holder measurements (Table 2), it can be concluded that the highest value of standard deviation occurs for the geometrical feature C2 (hook holder length) in both types of the hook holder. The thickness measurement showed that the values obtained were within the manufacturing precision limits of the 3D printer used (Table 4). This has been achieved thanks to a very precise saving of STL files in a customized mode with high resolution and a triangulation process.

From the results of the static tensile tests performed on the hook holders (Table 5), it was observed that the value of the mean maximum load force on hook holder B is $1.67 \%$ higher than the value of the maximum load force on hook holder A, so this is not a significant difference. Analyzing the results of measurements of selected geometrical features of the samples printed in three directions (Table 6), it was found that the largest 
cross-section had the sample printed in the $\mathrm{OZ}$ direction $\left(21.37 \mathrm{~mm}^{2}\right)$ and the smallest in the OY direction $\left(19.98 \mathrm{~mm}^{2}\right)$. Static tensile testing of samples printed in three directions (Table 6) showed that samples printed in the OX direction had the highest value $\overline{R_{m}}$ and this was $226.01 \%$ higher than the lowest value $\overline{R_{m}}$ in samples printed in the OZ direction. The results of the research confirm the previously conducted literature research, where the differences in the strength of the models produced for different orientations on the building platform were clearly indicated. However, the calculated differences are so large that they require taking into account additional safety factors for selected print variants, which significantly complicates the design and production of hook-type elements for medical/surgery application, which often work under load in several different axes. For samples printed in the OY direction, the value $\overline{R_{m}}$ was $209.16 \%$ higher than $\overline{R_{m}}$ samples printed in the OZ direction. The mechanical properties specified by the producer for MED610 material are presented for the material before printing. Therefore, for the OX axis, the values fluctuate in the range presented by the producer. In the case of samples printed on the OY axis, the values fluctuate around the lower values specified by the producer, i.e., $50 \mathrm{MPa}$. However, in the case of the $\mathrm{OZ}$ axis, the values are lower than those provided by the producer by $71 \%$. Based on the strength analysis performed in Solidworks (Figure 9), it was found that the stress concentration occurs at the largest radius of the hook holderfeature C7 (Figure 4). The highest local stress (mesh not densified) for the hook holder B was $90.5 \mathrm{MPa}$, while for the hook holder $\mathrm{A}$ it was $70 \mathrm{MPa}$. The difference is significant, the maximum stresses in the hook holder B being about $22 \%$ higher than those in the hook holder A. On the other hand, in the case of the mesh with increased local density, hook A and hook B were characterized by maximum stresses in the radius area equal to 80 and 93.9 $\mathrm{MPa}$, respectively. In this case, the difference was $17 \%$. The explanation of it is the fact that crack initiation does not only require a certain level of stress to be reached but also needs to fulfill an energy criterion and thus allows for local stresses larger than the material tensile strength; this phenomenon was fully described in the paper [37]. Such differences indicate that in the case of designing elements for the medical industry made of MED 610 material, additional corrections should be made in sensitive points, such as ribs or thickenings to prevent failures and increase the reliability of the device.

\section{Conclusions}

Based on the research results, it is possible to formulate the following general conclusions:

The dimension and shape precision analysis showed highly satisfactory precision, which is sufficient for applications in the medical industry.

Static tensile testing of samples printed in three directions showed an anisotropy of the mechanical properties of the material tested. The mean tensile strength in the OZ direction was $16 \mathrm{MPa}$, while in the OX direction it was $52.01 \mathrm{MPa}$, where the difference is equal to more than $200 \%$. This means that when designing this type of component, an appropriate safety factor must be adopted to reduce the allowable force transmitted by the hook holder, which will be manufactured using 3D printing technology.

The printed bio-element from MED 610 does not have electromagnetic properties, which is definitely an advantage, allowing the hook holder to work in the vicinity of heart or other organs that are susceptible to electromagnetic effects. A hook holder made with 3D printing technology can have any shape while retaining medical properties. Using biomedical materials, the Connex 350 printer is ideal for use in this field. The analysis of the obtained results allowed for the development of a further series of new designs to meet the requirements of modern materials more effectively, i.e., biodegradability, biotolerance and biofunctionality.

The optimum selection of printing parameters is necessary and important for the durability and functionality of the model. These parameters should be adjusted by the model designer, as only the model designer knows its purpose and functions. 


\begin{abstract}
Author Contributions: Conceptualization, T.K., J.B., P.Z. and D.G.; methodology, T.K. and J.B.; software, J.B. and P.S.; validation, J.B.; formal analysis, T.K. and J.B.; investigation, T.K., J.B., P.Z. and D.G.; resources, M.M., W.S., M.R. and P.S.; data curation, J.B., P.S., M.M. and W.S.; writing-original draft preparation, M.R. and P.S.; writing-review and editing, T.K., D.G., P.Z. and J.B.; visualization, P.S., W.S., M.R. and M.M.; supervision, T.K. and J.B.; project administration, T.K.; funding acquisition, T.K. and J.B. All authors have read and agreed to the published version of the manuscript.
\end{abstract}

Funding: The research was partially financed by the doctoral school at the Kielce University of Technology and the funds of the Faculty of Mechatronics and Machine Engineering at Kielce University of Technology. Moreover, this research was also partially funded by the National Science Center of Poland under the Miniatura 4, grant number 2020/04/X/ST5/00057 entitled: Analysis of polymer composites produced by $3 \mathrm{D}$ printing and electrospinning technologies in the applications of filtering devices.

\title{
Institutional Review Board Statement: Not applicable.
}

Informed Consent Statement: Not applicable.

Conflicts of Interest: The authors declare no conflict of interest.

\section{References}

1. Coakley, M.; Hurt, D.E. 3D Printing in the Laboratory: Maximize Time and Funds with Customized and Open-Source Labware. J. Lab. Autom. 2016, 21, 489-495. [CrossRef]

2. Provaggi, E.; Leong, J.J.H.; Kalaskar, D.M. Applications of 3D printing in the management of severe spinal conditions. Proc. Inst. Mech. Eng. Part H J. Eng. Med. 2017, 231, 471-486. [CrossRef]

3. Saharudin, M.S.; Hajnys, J.; Kozior, T.; Gogolewski, D.; Zmarzły, P. Quality of Surface Texture and Mechanical Properties of PLA and PA-Based Material Reinforced with Carbon Fibers Manufactured by FDM and CFF 3D Printing Technologies. Polymers 2021, 13, 1671. [CrossRef]

4. Bochnia, J.; Blasiak, S. Anisotrophy of mechanical properties of a material which is shaped incrementally using polyjet technology. In Proceedings of the 22nd International Conference Engineering Mechanics 2016, Svratka, Czech Republic, 9-12 May 2016.

5. Kozior, T. The Influence of Selected Selective Laser Sintering Technology Process Parameters on Stress Relaxation, Mass of Models, and Their Surface Texture Quality. 3D Print. Addit. Manuf. 2020, 7, 126-138. [CrossRef]

6. Pagáč, M.; Hajnyš, J.; Petrů, J.; ZLáMAL, T.; Šofer, M. The study of mechanical properties stainless steel 316L after production from metal powder with using additive technology and by method selective laser melting. In Proceedings of the METAL 2017-26th International Conference on Metallurgy and Materials, Conference Proceedings, Brno, Czech Republic, 24-26 May 2017.

7. Hanon, M.M.; Zsidai, L.; Ma, Q. Accuracy investigation of 3D printed PLA with various process parameters and different colors. Mater. Today Proc. 2021, 42, 3089-3096. [CrossRef]

8. Gogolewski, D.; Bartkowiak, T.; Kozior, T.; Zmarzły, P. Multiscale analysis of surface texture quality of models manufactured by laser powder-bed fusion technology and machining from 3161 steel. Materials 2021, 14, 2794. [CrossRef] [PubMed]

9. Adamczak, S.; Zmarzly, P.; Kozior, T.; Gogolewski, D. Assessment of Roundness and Waviness Deviations of Elements Produced By Selective Laser Sintering Technology. Eng. Mech. 2017, 2017, 70-73.

10. Paszkiewicz, A.; Bolanowski, M.; Budzik, G.; Przeszłowski, Ł.; Oleksy, M. Process of creating an integrated design and manufacturing environment as part of the structure of industry 4.0. Processes. 2020, 8, 1019. [CrossRef]

11. Fina, F.; Madla, C.M.; Goyanes, A.; Zhang, J.; Gaisford, S.; Basit, A.W. Fabricating 3D printed orally disintegrating printlets using selective laser sintering. Int. J. Pharm. 2018, 541, 101-107. [CrossRef]

12. Taormina, G.; Sciancalepore, C.; Messori, M.; Bondioli, F. 3D printing processes for photocurable polymeric materials: Technologies, materials, and future trends. J. Appl. Biomater. Funct. Mater. 2018, 16, 151-160. [CrossRef]

13. Rimann, M.; Bono, E.; Annaheim, H.; Bleisch, M.; Graf-Hausner, U. Standardized 3D Bioprinting of Soft Tissue Models with Human Primary Cells. J. Lab. Autom. 2016, 21, 496-509. [CrossRef] [PubMed]

14. Zmarzły, P. Technological heredity of the turning process. Teh. Vjesn. 2020, 27, 1194-1203. [CrossRef]

15. Kozior, T.; Mamun, A.; Trabelsi, M.; Wortmann, M.; Sabantina, L.; Ehrmann, A. Electrospinning on 3D printed polymers for mechanically stabilized filter composites. Polymers 2019, 11, 2034. [CrossRef]

16. Blachowicz, T.; Ehrmann, A. 3D printed MEMS technology-recent developments and applications. Micromachines 2020, 11, 434. [CrossRef]

17. Hanon, M.M.; Alshammas, Y.; Zsidai, L. Effect of print orientation and bronze existence on tribological and mechanical properties of 3D-printed bronze/PLA composite. Int. J. Adv. Manuf. Technol. 2020, 108, 553-570. [CrossRef]

18. Kabir, S.M.F.; Mathur, K.; Seyam, A.-F.M. The Road to Improved Fiber-Reinforced 3D Printing Technology. Technologies 2020, 8, 51. [CrossRef]

19. Barclift, M.W.; Williams, C.B. Examining variability in the mechanical properties of parts manufactured via polyjet direct 3D printing. In Proceedings of the 23rd Annual International Solid Freeform Fabrication Symposium-An Additive Manufacturing Conference, SFF 2012, Austin, TX, USA, 6-8 August 2012. 
20. Bandyopadhyay, A.; Bose, S.; Das, S. 3D printing of biomaterials. MRS Bull. 2015, 40, 108-115. [CrossRef]

21. Zmarzły, P.; Gogolewski, D.; Kozior, T. Design guidelines for plastic casting using 3D printing. J. Eng. Fiber. Fabr. 2020, 15, 1-10. [CrossRef]

22. Dziubek, T.; Sobolewski, B.; Filip, M. Development and evaluation of correction factors which increase the accuracy of models of research carried out in the form of geometric primitives for additive manufacturing methods PolyJet. Mechanik 2016. [CrossRef]

23. Šercer, M.; Rezic, T.; Godec, D.; Oros, D.; Pilipovic, A.; Ivušic, F.; Rezic, I.; Andlar, M.; Ludwig, R.; Šantek, B. Microreactor production by PolyJet Matrix 3D-printing technology: Hydrodynamic characterization. Food Technol. Biotechnol. 2019. [CrossRef] [PubMed]

24. Intuitive Da Vinci X/Xi Instrument \& Accessory Catalog November 2020. Available online: https://www.intuitive.com/en-us/ - / media / Project/Intuitive-surgical/files / pdf/xi-x-ina-catalog-no-pricing-us-1052082.pdf?la=en\&hash=189164507BDFEC4 0E9DAB44BA10731A5 (accessed on 19 January 2022).

25. Morley, T.A.; Baron, D.S.; Wallace, D.T. Minimally Invasive Surgical Hook Apparatus. Available online: https://patentimages storage.googleapis.com/bf/b0/07/357cb15148483d/US7276065B2.pdf (accessed on 21 December 2021).

26. Abuhav, I. ISO 13485: A Complete Guide to Quality Management in the Medical Device Industry; CRC Press: Boca Raton, FL, USA, 2011.

27. Bochnia, J.; Blasiak, M.; Kozior, T. Tensile strength analysis of thin-walled polymer glass fiber reinforced samples manufactured by $3 \mathrm{~d}$ printing technology. Polymers 2020, 12, 2783. [CrossRef]

28. Bochnia, J.; Blasiak, M.; Kozior, T. A Comparative Study of the Mechanical Properties of FDM 3D Prints Made of PLA and Carbon Fiber-Reinforced PLA for Thin-Walled Applications. Materials 2021, 14, 7062. [CrossRef] [PubMed]

29. Kitamori, H.; Sumida, I.; Tsujimoto, T.; Shimamoto, H.; Murakami, S.; Ohki, M. Evaluation of mouthpiece fixation devices for head and neck radiotherapy patients fabricated in PolyJet photopolymer by a 3D printer. Phys. Med. 2019. [CrossRef] [PubMed]

30. EN ISO 10993-5:2009; Biological Evaluation of Medical Devices-Part 5: Tests for In Vitro Cytotoxicity; ISO: Geneva, Switzerland, 2009.

31. EN ISO 10993-10:2013; Biological Evaluation of Medical Devices-Part 10: Tests for Irritation and Skin Sensitization; ISO: Geneva, Switzerland, 2013.

32. EN ISO 10993-3:2014; Biological Evaluation of Medical Devices-Part 3: Tests for Genotoxicity, Carcinogenicity and Reproductive Toxicit; ISO: Geneva, Switzerland, 2014.

33. EN ISO 10993-18:2009; Biological Evaluation of Medical Devices-Part 18: Chemical Characterization of Materials; ISO: Geneva, Switzerland, 2009.

34. Stratasys MSDS Clear Bio-Compatible MED610. Available online: https://www.sys-uk.com/wp-content/uploads/2016/01/ MSDS-Clear-Bio-Compatible-MED610-English-US-1.pdf (accessed on 21 December 2021).

35. Stratasys Biocompatible Clear MED610. Available online: https://cadxpert.pl/wp-content/uploads/2019/03/spec_PolyJet_ MED610_MED620.pdf (accessed on 21 December 2021).

36. Kozior, T.; Bochnia, J.; Zmarzły, P.; Gogolewski, D.; Mathia, T.G. Waviness of Freeform Surface Characterizations from Austenitic Stainless Steel (316L) Manufactured by 3D Printing-Selective Laser Melting (SLM) Technology. Materials 2020, 13, 4372. [CrossRef] [PubMed]

37. Doitrand, A.; Martin, E.; Leguillon, D. Numerical implementation of the coupled criterion: Matched asymptotic and full finite element approaches. Finite Elem. Anal. Des. 2020, 168, 103344. [CrossRef] 